\title{
New records of Biuve fulvipunctata (Baba, I938) (Gastropoda Cephalaspidea) and Taringa tritorquis Ortea, Perez et Llera, I 982 (Gastropoda Nudibranchia) in the Ionian coasts of Sicily, Mediterranean Sea
}

\author{
Andrea Lombardo* \& Giuliana Marletta
}

Department of Biological, Geological and Environmental Sciences, Section of Animal Biology, University of Catania, via Androne 81, 95124 Catania, Italy

*corresponding author, e-mail: andylombardo94@gmail.com.

\begin{abstract}
In the present paper, two sea slug species, Biuve fulvipunctata (Baba, 1938) (Gastropoda Cephalaspidea) and Taringa tritorquis Ortea, Perez \& Llera, 1982 (Gastropoda Nudibranchia), are reported for the second time in the Ionian coasts of Sicily (Italy). Biuve fulvipunctata is an Indo-West Pacific cefalaspidean, previously reported for Italian territorial waters only in Faro Lake (Messina, Sicily). Taringa tritorquis is a species originally described for Canary Islands and hitherto found in Sicily and probably in Madeira. Both species are easily identifiable for their characteristic external morphology. Indeed, B. fulvipunctata shows a W-shaped pattern of white pigment on the head, while T. tritorquis presents rhinophore and gill sheaths with spiculous tubercles crown-shaped and an orange-yellowish body coloring. Since B. fulvipuctata has been previously reported in Faro Lake, probably, the specimen reported in this note could have been taken in veliger stage through the Strait of Messina currents. Otherwise, the veliger has been carried attached to the keel of boats. Instead, it is still unclear if T. tritorquis could be a native or non-indigenous species of the Mediterranean Sea. Indeed, due to its small size and its sciaphilous behavior, it might be a rare species, overlooked until now.
\end{abstract}

KEY WORDS

Aglajidae; Biuve fulvipunctata; Discodorididae; Ionian Sea; Sicily; Taringa tritorquis.

Received 12.03.2020; accepted 13.05.2020; published online 30.06.2020

\section{INTRODUCTION}

Recently, two new sea slugs have been found along the central-eastern coast of Sicily. One of them, Biuve fulvipunctata (Baba, 1938) is an Indo-West Pacific cephalaspidean of the family Aglajidae Pilsbry, 1895 (1847) (Malaquias et al., 2016; Kousteni et al., 2019), while the other, Taringa tritorquis Ortea, Perez et Llera, 1982 is a rare nudibranch of the family Discodorididae Bergh, 1891.
Biuve fulvipunctata was reported for the first time in the Mediterranean Sea as Chelidonura mediterranea Swennen, 1961 in 1959, in Antalaya bay (Turkey) (Swennen, 1961). Then, C. mediterranea was considered as a junior synonym of $C$. fulvipunctata (Gosliner, 1980; Malaquias et al., 2016). Today, C. fulvipunctata has been attributed to the genus Biuve Zamora-Silva et Malaquias, 2017 (see Zamora-Silva et al., 2018). In this taxon the external colouring is very variable, with a range from blue with orange/yellow spots and few white patches to 
light/dark brown with small white dots. Nevertheless, this species always shows a distinctive Wshaped pattern of white pigment on the head (Zenetos et al., 2004; Kousteni et al., 2019). After the first report in 1959, this species had spread in great part of the Mediterranean Sea, reaching these following localities: Israel in 1986 (Mienis \& Gat, 1987), Maltese islands in 1993 (Perrone \& Sammut, 1997; Sammut \& Perrone,1998), Cyprus in 2003, 2006 (Tsiakkiros \& Zenetos, 2011), and 2015 (Malaquias et al., 2016), France in 2014 (Horst, 2015), Balearic islands (Spain) in 2015 (Karachle et al., 2016), Sicily (Italy) in 2015 (Malaquias et al., 2016) and Croatia in 2018 (Kousteni et al., 2019). Moreover, since this species has been found in the Red Sea only twice (Galil et al., 2016), Malaquias et al. (2016) hypothesized that B. fulvipunctata entered the Red Sea through the Mediterranean Sea. After that, Galil et al. (2016) have questioned the veracity of this hypothesis. However, to date, the dispersal path of this species is still unknown.

Taring a tritorquis was described by Ortea et al. (1982) based on the finding of three specimens at a depth of $3 \mathrm{~m}$ in Lanzarote (Canary Islands). In the original description, it was highlighted a difference in the coloring of specimens with different sizes: individuals of $6 \mathrm{~mm}$ have a red-violet body, darker in the middle part and pinker towards the edges of the mantle, while the smaller specimens, of 4-5 $\mathrm{mm}$, are pinkish-yellow with a darker visceral zone. In all specimens on the notum, there are numerous dark maroon spots with an irregular distribution. Moreover, the notum presents spaced tubercles which have the same shape and color on all the back. The gill is formed by six uni-bipinnate white leaves with red spots. The leaves have a wide triangular rachis and the edge of the rhinophore and gill sheaths have white, spiculous tubercles crown-shaped. Rhinophore sheaths have 6-8 tubercles of this type, while gill sheath has 10 ones. Rhinophores are yellowish-white, with whitish lamellae and some dark spots. Finally, rhinophores have a heart-shaped section, with an anterior groove. Therefore, according to Ortea et al. (1982), this species differs for its distinct external morphology, due to the presence of characteristic tubercles in the rhinophore and the gill sheaths and for the coloring. The first report of $T$. tritorquis in the Mediterranean Sea was based on the finding of two specimens in a station called Santa Maria La Scala, located along the Ionian coast of Sicily (Lombardo \& Marletta in Gerovasileiou et al., 2020).

The aim of this paper is to report the second record of B. fulvipunctata for the Ionian coasts of Sicily and the second record of $T$. tritorquis for the whole Mediterranean basin. Additional data on these two species are provided.
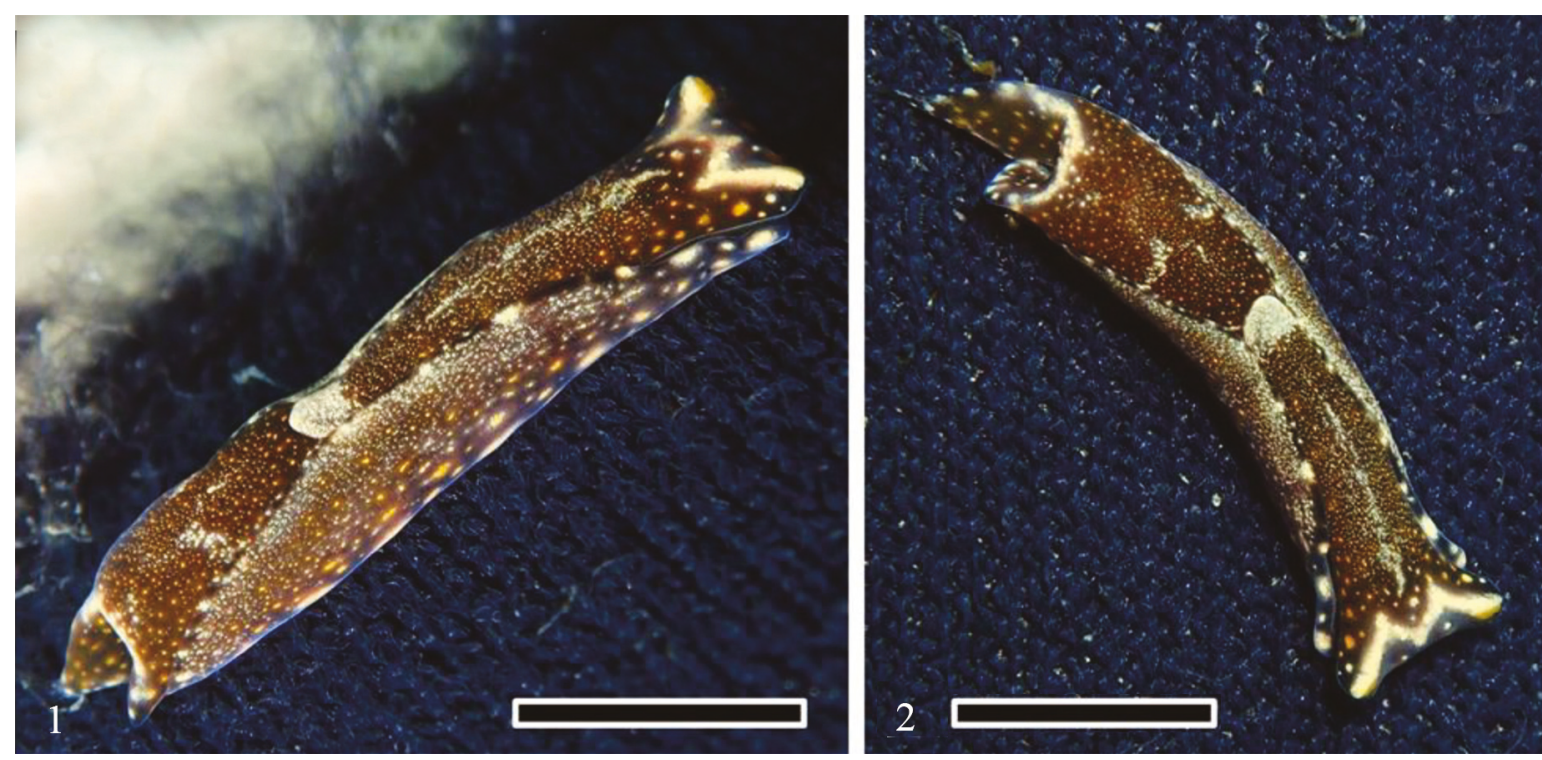

Figures 1, 2. Biuve fulvipunctata from Santa Tecla (Ionian Sea, Italy).

Fig. 2: dorsal view. Scale bars: $5 \mathrm{~mm}$. (photos A. Lombardo) 

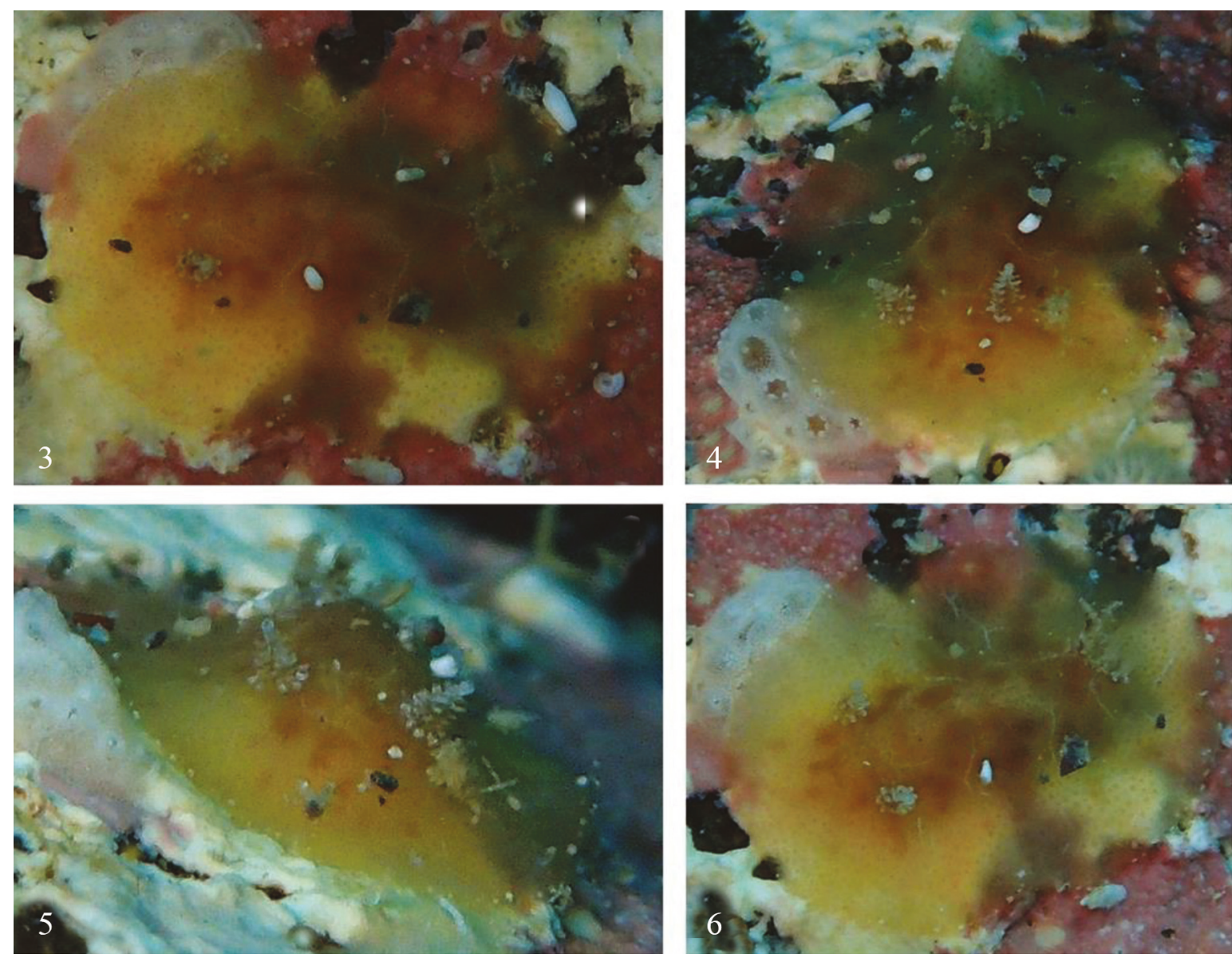

Figures 3-6. Taringa tritorquis found in Ognina (Ionian Sea). Fig. 3: dorsal view of the specimen. Fig. 4: antero-dorsal view of the specimen. Fig. 5: front view of the specimen Fig. 6: dorsal view of the specimen showing slight white lines arranged transversally (photos A. Lombardo)

\section{MATERIAL AND METHODS}

The B. fulvipuctata specimen was found in a station called Santa Tecla (37.639923 N, 15.184157 E) in the municipality of Acireale, while the T. tritorquis specimen was observed in a station called Ognina (37³1'51.7152” N, 157'10.5672” E), in the municipality of Catania. Both sites are located along the central-eastern coast of Sicily (Italy). Santa Tecla is a fishing town, which hosts a small touristic port. In particular, the specimen was found in an area near the harbour. Instead, Ognina is a strongly anthropized site, because of the coastal overexploitation, due to the presence of a harbour and a large number of apartment buildings. Geologically, the whole sector is characterized by subvolcanic rocks: columnar basalts and effusive submarine products forming fields of pillow lavas
(Sciuto et al., 2017). Both specimens were identified in vivo and photographed by an Olympus TG4 Underwater Camera during two different scuba dives conducted by the authors.

\section{RESULTS}

On 27th July 2019, a specimen of B. fulvipunctata (Figs. 1,2) was found at a depth of $4.4 \mathrm{~m}$ on a thallus of Padina pavonica (Linnaeus) Thivy. The specimen was $1.5 \mathrm{~cm}$ long and it had a dark blue body colouring with yellowish-orange spots scattered on the surface. On the anterior part of the cephalic shield, it presented a large white W-shaped sign with a yellow edging, which is a diagnostic feature of this species (Swennen, 1961; Malaquias et al., 2016; Kousteni et al., 2019). On the cephalic 
shield there was also a white stripe, formed by numerous white dots, in an anterior-posterior direction. The posterior apex of the cephalic shield showed a lot of such points, appearing completely white. Moreover, these white dots were present also along the upper flank of parapods and formed two small transverse stripes on the surface of the visceral hump. The edges of parapods and the posterior limit of the visceral hump presented a row of greater conspicuous white dots. Instead, the T. tritorquis specimen (Figs. 3-6) was found on 29th February 2020 at a depth of $6.9 \mathrm{~m}$, under a stone covered by sponges. The specimen was about $8 \mathrm{~mm}$ long and had an orange-yellowish body, with the middle part of the notum darker than the marginal parts. On the notum there were orange-brownish patches irregularly distributed mostly in the middle part and dots of the same coloring distributed on all the surface. Both gill and rhinophores were white with maroon spots. Rhinophores had a heart-shaped section. The edge of notum presented bright white dots. The edge of rhinophore and gill sheaths had white spiculous tubercles with a crown shaped. On the notum, there were slight white lines resembling scars, most of which transversely arranged. Therefore, this specimen perfectly corresponds to the first specimen found in Santa Maria La Scala and depicted by Lombardo \& Marletta (Gerovasileiou et al., 2020: Fig. 1A). The only difference between these individuals is that the specimen of Santa Maria La Scala presented the slight white lines resembling scars arranged longitudinally.

\section{DISCUSSION}

This short note reports the second record of $B$. fulvipunctata in Sicily, after that of Faro Lake (Messina) (Malaquias et al., 2016) and the second record of T. tritorquis in the Mediterranean Sea. A case similar to that of B. fulvipunctata occurred for another species, Godiva quadricolor (Barnard, 1927), a nudibranch of the family Facelinidae Bergh, 1889. In fact, this latter species was found in Faro Lake with stable populations (Furfaro et al., 2018) and then was seen in 2018 in Santa Maria La Scala (Lombardo \& Marletta, 2019), a station located near Santa Tecla. Even for B. fulvipunctata, many adults' specimens were observed in Faro Lake with established populations (Malaquias et al.,
2016). Therefore, as hypothesized by Lombardo and Marletta (2019) for G. quadricolor, the B. fulvipunctata specimen could have been carried in veliger stage through the Strait of Messina currents. Another hypothesis could be that the veliger of this species has travelled attached to the keel of some boats and has been brought directly in Santa Tecla.

Instead, the actual distribution of $T$. tritorquis includes Canary Islands, Sicily and probably Madeira (Lombardo \& Marletta in Gerovasileiou et al., 2020). Since in Sicily three specimens have been observed throughout three years (from 2018 to 2020), it could be hypothesized that $T$. tritorquis has settled in this area. However, since this species was documented only twice in the Mediterranean Sea (Lombardo \& Marletta in Gerovasileiou et al., 2020; present work), there are not enough data to define if $T$. tritorquis is a native or non-indigenous species. Indeed, because of its small size and cryptic behavior, this species is not easy to detect and probably is rare and has been overlooked until now.

Overall, through the present data and the previous observations (Ortea et al., 1982; Lombardo \& Marletta in Gerovasileiou et al., 2020), it was checked that $T$. tritorquis is a sciaphilous species that lives in shallow waters (within $10 \mathrm{~m}$ ), among algae or under the stones probably feeding on sponges, as other species of the genus Taringa (Perrone, 1985).

\section{REFERENCES}

Gerovasileiou V., Akyol O., Al-Hosne Z., Alshikh Rasheed R., Ataç E., Bello G., Ćetković I., CorsiniFoka M., Crocetta F., Denitto F., Guidetti P., Gül B., Insacco G., Jimenez C., Licchelli C., Lipej L., Lombardo A., Mancini E., Marletta G., Michailidis N., Pešić A., Poursanidis D., Refes W., Sahraoui H., Thasitis I., Tiralongo F., Tosunoğlu Z., Trkov D., Vazzana A. \& Zava B., 2020. New records of rare species in the Mediterranean Sea (May 2020). Mediterranean Marine Science, 0: 340-359. https://doi.org/10.12681 $/ \mathrm{mms} .22148$

Furfaro G., De Matteo S., Mariottini P. \& Giacobbe S., 2018. Ecological notes of the alien species Godiva quadricolor (Gastropoda: Nudibranchia) occurring in Faro Lake (Italy). Journal of Natural History, 52: 645-657. https://doi.org/10.1080/00222933.2018. 1445788

Galil B. S., Douek J., Mienis H. K. \& Rinkevich B., 2016. Comments on "The Mediterranean Sea as a 
gateway for invasion of the Red Sea: the case of the Indo-West Pacific head-shield slug Chelidonura fulvipunctata Baba, 1938" by Manuel António E. Malaquias, Andrea Zamora-Silva, Dyana Vitale, Andrea Spinelli, Sergio De Matteo, Salvatore Giacobbe, Deneb Ortigosa and Juan L. Cervera, Aquatic Invasions, 2016. Aquatic Invasions, 11: 351-354. http:// dx.doi.org/10.3391/ai.2016.11.4.01

Gosliner T. M., 1980. Systematics and phylogeny of the Aglajidae (Opisthobranchia: Mollusca). Zoological Journal of the Linnean Society, 68: 325-360. http: //dx.doi.org/10.1111/j.1096-3642.1980.tb01925.x

Horst B., 2015. Premier signalement d'un spécimen vivant de Chelidonura fulvipunctata (Gastropoda: Cephalaspidea: Aglajidae) en Méditerranée occidentale, sur les côtes françaises. Xenophora, 150: 18-20.

Karachle P.K., Angelidis A., Apostolopoulos G., Ayas D., Ballesteros M., Bonnici C., Brodersen M. M., Castriota L., Chalari N., Cottalorda J. M., Crocetta F., Deidun A., Đođo Ž., Dogrammatzi A., Dulčić J., Fiorentino F., Gönülal O., Harmelin J.G., Insacco G., Izquierdo-Gómez D., Izquierdo-Muñoz A., Joksimović A., Kavadas S., Malaquias M. A. E., Madrenas E-, Massi D., Micarelli P., Minchin D., Önal U., Ovalis P., Poursanidis D., Siapatis A., Sperone E., Spinelli A., Stamouli C., Tiralongo F., Tunçer S., Yaglioglu D., Zava B. \& Zenetos A., 2016. New Mediterranean Biodiversity Records (March 2016). Mediterranean Marine Science, 17: 230-252.

Kousteni V., Bakiu R.A., Benhmida A., Crocetta F., Di Martino V., Dogrammatzi A., Doumpas N., Durmishaj S., Giovos I., Gökoğlu M., Huseyinoglu M. F., Jimenez C., Kalogirou S., Kleitou P., Lipej L., Macali A., Petani A., Petović S., Prato E., Rubino F., Sghaier Y. R., Stancanelli B., Teker S., Tiralongo F. \& Trkov D., 2019. New Mediterranean biodiversity records (April, 2019). Mediterranean Marine Science, 20: 230-247. http://dx.doi.org/10.12681 /mms.19609

Lombardo A. \& Marletta G., 2019. Presence of the alien species Godiva quadricolor (Barnard, 1927) (Gastropoda Nudibranchia) along the coast of eastern Sicily. Biodiversity Journal, 10: 147-150. https:// doi.org/10.31396/Biodiv.Jour.2019.10.2.147.150
Malaquias M. A, Zamora-Silva A., Vitale D., Spinelli A., De Matteo S., Giacobbe S., Ortigosa D. \& Cervera J. L., 2016. The Mediterranean Sea as a gateway for invasion of the Red Sea: the case of the Indo-West Pacific head-shield slug Chelidonura fulvipunctata Baba, 1938. Aquatic Invasions, 11: 247-255. http:// dx.doi.org/10.3391/ai.2016.11.3.03

Mienis H. K. \& Gat G., 1987. A record of the Indo-Pacific species Chelidonura fulvipunctata from the Mediterranean coast of Israel (Opisthobranchia, Aglajidae). Levantina, 67: 709-711.

Ortea J. A., Perez J. M. \& Llera E., 1982. Molluscos Opistobranquios recolectados durante el Plan de Bentos Circuncanario. Doridacea: primera parte. Cuadernos del Crinas, 3: 1-48.

Perrone A.S., 1985. Una nuova specie di Nudibranchi Doridiani del litorale salentino: Taringa pinoi $\mathrm{n}$. sp. Thalassia Salentina, 15: 75-88.

Perrone A. S. \& Sammut C., 1997. Opisthobranchia of the genus Chelidonura Adams, 1850 (Cephalaspidea) from the Isle of Malta. Basteria, 61: 61-70.

Sammut C. \& Perrone A. S., 1998. A preliminary checklist of Opisthobranchia (Mollusca, Gastropoda) from the Maltese islands. Basteria, 62: 221-240.

Sciuto F., Rosso A., Sanfilippo R., Alongi G., Catra M., Serio D., Bejaoui S., Leonardi R. \& Viola A., 2017. First data on ostracods and foraminifera living in Cystoseira associations in western Ionian Sea. Mediterranean Marine Science, 18/3: 393-405. https://doi.org/10.12681/mms.2085

Swennen C., 1961. On a collection of Opisthobranchia from Turkey. Zoologische Mededelingen, 38: 41-75.

Tsiakkiros L. \& Zenetos A., 2011. Further additions to the alien mollusc fauna along the Cypriot coast: new Opisthobranchia species. Acta Adriatica, 52: 115124.

Zamora-Silva A. \& Malaquias M. A., 2018. Molecular phylogeny of the Aglajidae head-shield sea slugs (Heterobranchia: Cephalaspidea): new evolutionary lineages revealed and proposal of a new classification. Zoological Journal of the Linnean Society, XX: 1-51. http://dx.doi.org/10.1093/zoolinnean/zlx064

Zenetos A., Gofas S., Russo G. \& Templado J., 2004. CIESM Atlas of Exotic Species in the Mediterranean. Vol. 3. Molluscs. CIESM Publishers, Monaco, 376 pp. 
